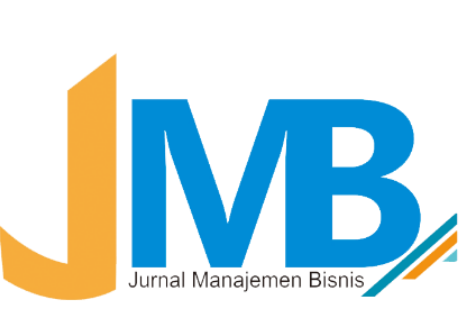

\title{
SHOPPING LIFESTYLE AS MEDIATING BETWEEN HEDONIC SHOPPING ON IMPULSE BUYING ONLINE AT MARKETPLACE
}

Viajeng Purnama Putri

Management Department. Muhammadiyah University of Malang, East Java, Indonesia

Corresponding Author's Email:vajengputri@umm.ac.id

Received: 05-09-2020 | Revision: 20-09-2020| Accepted: 20-10-2020

To cite this document:

Putri, Viajeng P, (2020) "Shopping lifestyle as mediating between hedonic shopping and on impulse buying online at marketplace", Manajemen Bisnis, Vol. 10, No. 02, pp 01-08, http://ejournal.umm.ac.id/index.php/jmb/issue/view/14496

\begin{abstract}
This study is to test the effect of hedonic shopping, shopping lifestyle to impulse buying online. This research sample of 100 respondents, taken based on purposive sampling. The data analysis uses PLSsoftware3. This path analysis technique will be used in testing the amount of contribution shown by the path coefficient on each path diagram of the causal relationship between variables Hedonic shopping (HS), Shopping Lifestyle (SL), on Impulse Buying (IB). Hedonic shopping support have a positive and significant effect on impulse buying. Positive shopping lifestyle effect on impulse buying and shopping lifestyle able to mediate the effect between hedonic shopping on impulse buying. Hedonic shopping and shopping lifestyle had positively and significantly influenced the consumer's responses to impulse buying.
\end{abstract}

Keywords: Hedonic shopping, shopping lifestyle, impulse buying.

\section{INTRODUCTION}

Technology developments have affected Indonesian society in general with the use of the internet in everyday life. Internet is used to access all kinds of information, from political, economic, social and cultural. Based on data from APJII, it shows that internet usage in Indonesia in 2018 was $64.8 \%$. The internet is not only for searching information and communication tools, but also for using the internet for trading or transacting online. Trade transactions through online that connect between sellers and buyers are known as e-commerce(Rutuja et al., 2020). Online shopping makes it easy for consumers to take advantage of shorter shopping time without going around shopping centers looking for the desired itemKahraman (2017). Access to various online stores can be done in a short time by visiting many online stores at once.

Mobile phones make it easier for consumers to access online shops that are widespread online. Not only easy access and transactions, online shops sometimes also offer special prices for each product and certain brands with product models that have many choices to attract consumersPark \& Kim (2003). Ease of accessing online stores anywhere and anytime, most important being connected to the internet affects the shopping style of consumers and ultimately encourages or influences consumers to 
make unplanned purchases(Saputra et al., 2020), (Dash, 2019). The behavior of consumers who make unplanned purchases is known as impulse buying. This unplanned purchase happened suddenly without going through much consideration of the consequences, which usually happens to new products such as new products launched at promo prices (Zhang et al., 2018).

These purchases are driven by consumer behavior which broadens the focus into a strong impulse that appears instantaneously in purchasing behavior. This is due to the rise of e-commerce and the constant buying of something nowadays, followed by financial technology startups that have dominated the feeling and excitement of being sated. Unplanned purchases are another form of consumer buying patterns that are not specifically planned. Consumers making impulsive purchases will tend not to consider the consequences(Aragoncillo \& Orús, 2018), (Akram et al., 2018),(Himawari et al., 2018). The value of impulsive spending is increasing in line with economic progress and people's lifestyles. In line with that, many studies have looked at the factors driving impulsive consumer shopping behavior(Dodoo \& Wu, 2019). According to(Stieler \& Germelmann, 2016), impulse buying behavior is influenced by hedonic shopping value. Hedonic shopping value reflects the shopping potential and emotional value of consumers in shopping, as for most people shopping is fun, joyful and can relieve stress. Consumers are more likely to engage in impulse buying behavior when they are motivated by hedonic needs and desires, such as pleasure, fantasy and social or emotional gratification. Hedonic shopping value also affects consumer shopping lifestyle, where shopping lifestyle reflects a person's choice of spending time and money. Online shopping provides convenience that can save consumers shopping time, where in a relatively short time they can explore many online stores at once. This provides a distinct experience for online shop consumers.

\section{LITERATURE REVIEW}

Impulse buying is buying behavior in which consumers do not consider buying, or consider buying, but have not yet decided what product to buy. In purchasing products, one consumer's behavior can be very different from another. One group of buyers may plan their purchases carefully before going to the store, so this group tends to carry a shopping list (Chan, Cheung, \& Lee, 2017). According to(Verplanken \& Herabadi, 2001)There are two important aspects in impulsive buying, namely: a. cognitive: This aspect focuses on the conflict that occurs in individual cognitive which includes: 1) Purchasing activities that are carried out without considering the price of a product. 2) Purchasing activities without considering the use of a product. 3) Individuals do not do product comparisons. (Affective): This aspect focuses on the emotional condition of consumers which includes: 1) The urge to immediately make a purchase. 2) There are feelings of disappointment that arise after making a purchase. 3) There is a purchase process that is carried out without planning. Impulse Buying Dimensions According to(Verhagen \& Van Dolen, 2011) states that there are three dimensions of impulse buying, which consist of: 1 . Spontaneity 2. Unplanned purchases 3. On-site decision making.

Shopping lifestyle according to Japarianto (2011: 33), is an expression of lifestyle in shopping that reflects differences in social status. The way we shop reflects status, dignity, and habits. Shopping lifestyle shows the way someone chooses to 


\section{Shopping lifestyle as mediating between hedonic shopping on impulse buying online at marketplace}

allocate income, both in terms of allocating funds for various products and services, as well as certain alternatives in the differentiation of similar categories (Japarianto 2011: 12). From these definitions, a shopping lifestyle is how a person spends their time and money, which of these activities can reflect a person's status, dignity and habits. Shopping Lifestyle Dimensions According toLiu \& Tsai (2010) said the shopping lifestyle is conceptualized into three dimensions as follows: 1. Activities 2. Interest 3. Opinions

Hedonic Shopping, shopping for everyone is a fun activity. In every person, of course, has a hedonistic nature. This hedonistic nature appears when someone is in a shopping center. According to Scarpi(Scarpi, 2006)argues that hedonic shopping describes the value of a shopping experience that includes fantasy, censorship of stimulation, joy, pleasure, curiosity and delusion of joy. According to(Kusuma et al., 2013)There are several categories of hedonic shopping including adventure shopping, which is shopping for a trip, done for adventure and experiencing a different world, and gratification shopping, which is shopping done with the aim of relieving stress, reducing boredom, and to please yourself. When consumers are hedonic, consumers no longer think that the products they buy have an advantage or benefit for them. A person's shopping style is determined by shopping motivation where a consumer who has a high hedonic motivation, there is a possibility that his shopping style is also getting more and more excessive "(Lumintang, 2012). Hedonic consumption reflects an instrument that directly presents the benefits of a shopping experience, such as pleasure and novelty (Samuel, 2005).

According to (Arnold \& Reynolds, 2003)there are several categories of hedonic shopping including adventure shopping, social shopping, gratification shopping, idea shopping, role shopping, value shopping. Based on the literature review and the previous studies about e-servicescape, perceived service quality, and intention to use, so the hypotheses that proposed in this study are H1. Shoping Lifestyle has a positive and significant effect on impulse buying. H2. Hedonic Shopping Value has a positive and significant effect on impulse buying. H3. Hedonic Shopping Value has a positive and significant effect on Shopping life style. H4. Shopping lifestyle could mediate the influence of the Hedonic Shopping value to impulse buying. The research framework of this study, as seen in Figure 1.

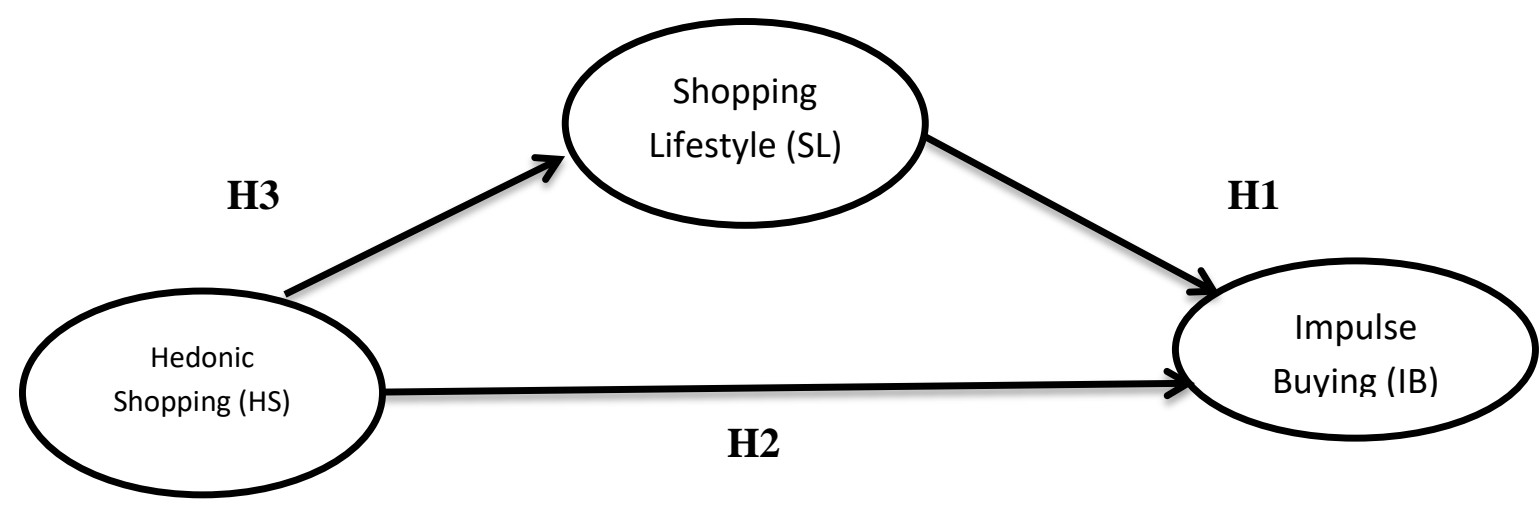

Figure 1. Research Framework 


\section{RESEARCH METHOD}

The type of research used in this research is explanatory research. This explanatory research is intended to determine the size of the influence between the independent variable and the dependent variable. The population in this study were all online consumers whose numbers were not known with certainty (indefinite). The number of samples is 100 respondents. The sampling technique used accidental sampling and purposive sampling, namely using certain conditions such as: (1) at least 18 years-50 years old (2) having made unplanned purchases at least 2 times a year in an online shop. The data of this study was measure in 5 rates Likert's scale and then analyzed using Partial Least Square Method with SmartPLS3 software.

\section{RESULT AND DISCUSSION}

The collected data in this study were analyzed using Partial Least Square Method with SmartPLS3 software. it is necessary to test the validity and reliability of the data that will be used in the analysis. Referring to Holmes-Smith (2001), an indicator is declared valid if the t-statistic value is $>1.96$, The criteria of this test are the outer loading coefficient, or the loading factor of each item must be greater or equal than 0.700 ( Hair, Hopkins, \& Kuppelwieser, 2014. An instrument is reliable when it has composite reliability and Cronbach Alpha's value is greater or equal than 0.700 . And the value AVE must be greater or equal than 0.500 (Hair et al., 2014). Validity testing for the questionnaire instrument is shown in Table 1 below, it is known that the entire questionnaire instrument is valid.

Table 1. Validity Test

\begin{tabular}{|c|c|c|c|c|}
\hline & Outer Loading & STDEV & t- Statistics & p-value \\
\hline $\mathrm{HS} 1 \leftarrow \mathrm{HS}$ & 0851 & 0.030 & 28,222 & 0.000 \\
\hline $\mathrm{HS} 2 \leftarrow \mathrm{HS}$ & 0.922 & 0.015 & 60,989 & 0.000 \\
\hline $\mathrm{HS} 3 \leftarrow \mathrm{HS}$ & 0.719 & 0.066 & 10,968 & 0.000 \\
\hline $\mathrm{HS} 4 \leftarrow \mathrm{HS}$ & 0.776 & 0.030 & 25,876 & 0.000 \\
\hline $\mathrm{IB} 1 \leftarrow \mathrm{IB}$ & 0.964 & 0.009 & 109,261 & 0.000 \\
\hline $\mathrm{IB} 2 \leftarrow \mathrm{IB}$ & 0.756 & 0.041 & 18,415 & 0.000 \\
\hline $\mathrm{IB} 3 \leftarrow \mathrm{IB}$ & 0.931 & 0.022 & 42,546 & 0.000 \\
\hline $\mathrm{IB} 4 \leftarrow \mathrm{IB}$ & 0.948 & 0.018 & 52,809 & 0.000 \\
\hline $\mathrm{SL} 1 \leftarrow \mathrm{SL}$ & 0.768 & 0.034 & 22,575 & 0.000 \\
\hline $\mathrm{SL} 2 \leftarrow \mathrm{SL}$ & 0.694 & 0.053 & 12,975 & 0.000 \\
\hline $\mathrm{SL} 3 \leftarrow \mathrm{SL}$ & 0.822 & 0.038 & 21,652 & 0.000 \\
\hline $\mathrm{SL} 4 \leftarrow \mathrm{SL}$ & 0.721 & 0.067 & 10,786 & 0.000 \\
\hline
\end{tabular}

After it is known that all instruments meet the validity requirements, then the instrument reliability test is carried out. This test is conducted to determine the extent to which measuring instruments can be trusted or relied on. Based on Table 2 below, it shows that the alpha value of the research instrument in each variable is equal to or greater than the required value of 0.60 , thus the research data can be said that the entire questionnaire instrument is valid and reliable ready to be tested further, because it has met the minimum requirements, as expressed by Sekaran (2000): 


\section{Shopping lifestyle as mediating between hedonic shopping on impulse buying online at marketplace}

Table 2. Reliability Test

\begin{tabular}{llll}
\hline & AVE & $\begin{array}{l}\text { Composite } \\
\text { Reliability }\end{array}$ & Cronbachs Alpha \\
\hline HS & 0.673 & 0891 & 0842 \\
IB & 0816 & 0.946 & 0.922 \\
SL & 0.567 & 0.839 & 0.748 \\
\hline
\end{tabular}

The results of the data analysis explain the influence of shopping lifestyle, hedonic shopping on impulse buying directly or indirectly through mediation as shown in Figure 2 .

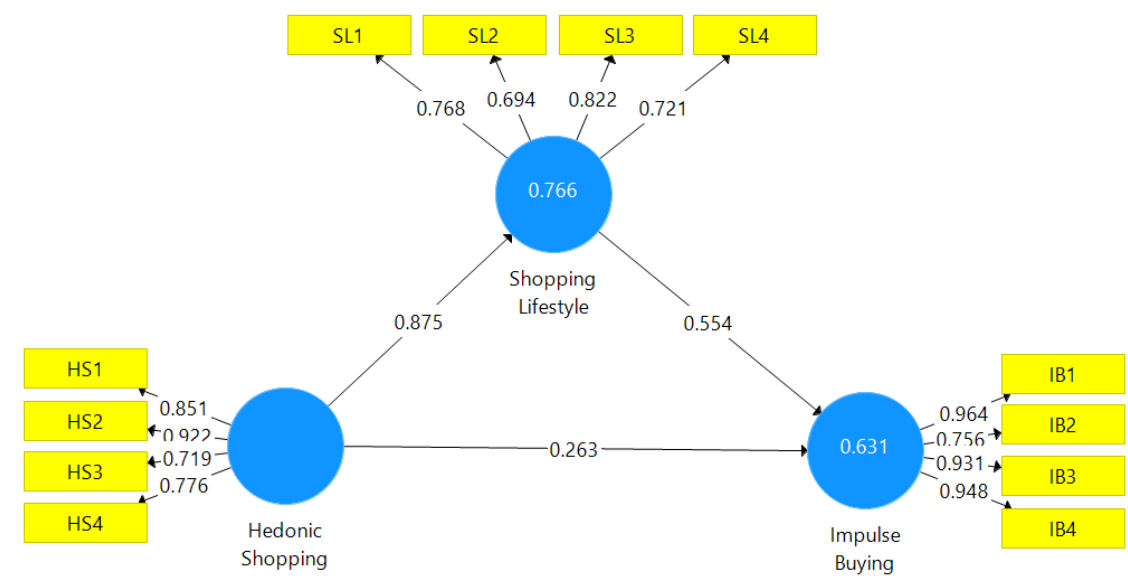

Figure 2. Result of Research

The following results of the direct effect statistical test are presented in table 3 below:

Table 3. The results of the analysis of the direct effect of the Variable Relationship Hypothesis

\begin{tabular}{llllll}
\hline & & \multicolumn{3}{c}{ Estimate } & \\
\cline { 3 - 4 } Hypothesis & Variable & Path & t-statistic & p-value & Information \\
& Relationships & coefficient & & & \\
H1 & SL $\rightarrow$ IB & 0.554 & 6,245 & 0.007 & Accepted \\
H2 & HS $\rightarrow$ IB & 0.263 & 2,720 & 0.000 & Accepted \\
H3 & HS $\rightarrow$ SL & 0.875 & 36,775 & 0.000 & Accepted \\
\hline
\end{tabular}

Based on Table 3, it can be seen that: Shopping Lifestyle (SL) has a positive and significant effect on online impulse buying (IB) in the marketplace. This is evidenced by the path value of the coefficient of 0.554 and a significant level of 0.007 . Because $t-$ statistic $>1.96$ and p-value $<0.05$, the effect is significant. Thus, hypothesis 1 is accepted. The effect of hedonic shopping (HS) on Impulse Buying (IB) is significant at the coefficient value of 0.263 and t-statistic of 2,720. Because t-statistic $>1.96$ and p- 
value $<0.05$, hedonic shopping has a significant effect on impulse buying (IB). This, hypothesis 2 is accepted. The influence of hedonic shopping on shopping lifestyle is significant at the coefficient value of 0.875 and $t$-statistic 36,775 . Because the $t-$ statistic $>1.96$ and p-value $<0.05$, it has a significant effect. Therefore, hypothesis 3 is accepted. This is in accordance with research conducted by Pattipeilohy, Rofiaty, \& Idrus (2013), Saran et al., (2016) who also found that impulse buying can occur due to the hedonic consumption of visitors. Consumers can be directly moved to make purchases impulsively because of the desire to fulfill their personal needs, for example, to just pamper themselves. The results of this study are in line with research conducted by Okada (2007) which states that consumer lifestyles such as lifestyle in dealing with other people, innovative lifestyles, price-oriented lifestyles have been tested to influence purchasing behavior. From the calculation of the total effect in this research model, it proves that the variables of this study,

Table 4. Indirect Effect

\begin{tabular}{|c|c|c|c|c|c|}
\hline & $\begin{array}{l}\text { Original } \\
\text { Sample }\end{array}$ & STDEV & t- statistic & p-value & Information \\
\hline$\underset{\rightarrow \mathrm{IB}}{\mathrm{HS}} \rightarrow \mathrm{SL}$ & 0.485 & 0.083 & 5,853 & 0.000 & Significant \\
\hline
\end{tabular}

Shopping Lifestyle mediates hedonic shopping against impulse buying. The results of the analysis obtained a t-statistic value of 5,853> 1.96 and a p-value of 0.00 $<0.05$, so the effect was significant. So we can infer that shopping lifestyle in mediating the influence of hedonic shopping to impulse buying, or H4 is accepted. Furthermore, the path coefficient of the indirect effect is 0.485 which is greater than its direct effect, 0.263 , so that shopping lifestyle fully mediated the influence of hedonic shopping to impulse buying. The results of this study are in line with research conducted by Gültekin and Özer (2012) which states that hedonic shopping motives have a significant effect on impulse buying. The results of the indirect effect of the hedonic shopping variable on impulse buying through the shopping lifestyle variable.

\section{CONCLUSION}

Based on the analysis of the influence of hedonic shopping and shopping lifestyle on impulse buying, the following conclusions can be drawn: hedonic shopping is able to influence impulse buying. Shopping lifestyle can directly influence impulse buying. Shopping lifestyle also mediates the relationship between hedonic shopping and impulse buying. The findings of this study indicate that shopping lifestyle can directly influence impulse buying, hedonic shopping will have a greater effect on impulse buying when it is mediated by shopping lifestyle, it is necessary to start by preparing consumer lifestyle needs for the benefit of the company, where shopping lifestyle support affects the formation of impulses. buying consumer, which then becomes the company 's strength in making changes Consumers who always enjoy shopping time can be used as an opportunity to increase sales by offering quality products, products that are in high demand, as well as taking advantage of price offers that can attract consumer attention such as purchase promos and discounts or discounts. Thus it is able to increase the sales volume that the company wants to achieve. 


\section{Shopping lifestyle as mediating between hedonic shopping on impulse buying online at marketplace}

\section{REFERENCES}

Akram, U., Hui, P., Khan, MK, Yan, C., \& Akram, Z. (2018). Factors affecting online impulse buying: Evidence from Chinese social commerce environment. Sustainability (Switzerland), 10 (2). https://doi.org/10.3390/su10020352

Aragoncillo, L., \& Orús, C. (2018). Impulse buying behavior: An online-offline comparative and the impact of social media. Spanish Journal of Marketing - ESIC, 22 (1), 42-62. https://doi.org/10.1108/SJME-03-2018-007

Arnold, MJ, \& Reynolds, KE (2003). Hedonic shopping motivations. Journal of Retailing, 79 (2), 77-95. https://doi.org/10.1016/S0022-4359(03)00007-1

Chan, TKH, Cheung, CMK, \& Lee, ZWY (2017). The state of online impulsiveness research: A literature analysis. Information and Management, 54 (2), 204-217. https://doi.org/10.1016/j.im.2016.06.001

Dash, PLN (2019). Influence Of Attitude And Lifestyle On Online Shopping Among Young College And University Going Youths: A Case Of Bhubaneswar And Cuttack City, Odisha.

Dodoo, NA, \& Wu, L. (2019). Exploring the anteceding impact of personalized social media advertising on online impulse buying tendency. International Journal of Internet Marketing and Advertising, 13 (1), 73-95. https://doi.org/10.1504/IJIMA.2019.097905

Gültekin, B., and Özer L., 2012, The Influence of Hedonic Motives and Browsing On Impulse Buying, Journal of Economics and Behavioral Studies, Vol. 4, No. 3, March: pp. 180-189, (ISNN: 2220-6140)

Himawari, RC, Prayoga, T., Fajrianti, SP, \& Abraham, J. (2018). Online impulse buying: The role of self-construction and online shop aesthetics. International Journal on Advanced Science, Engineering and Information Technology, 8 (5), 1926-1933. https://doi.org/10.18517/ijaseit.8.5.1587

Kahraman, A. (2017). Adopting Brand Values to Internal Customers: Case of Vestel Inc Hasan Arslan / Mehmet Al i İçbay / Madalina Tomescu Communication and Digital Media (Issue December).

Kusuma, GW, Idrus, S., \& Djazuli, A. (2013). The Influence of Hedonic Shopping Motivations on Buying Decision with Gender as Dummy Variable: (A Study on Consumers at the Hardy's Mall Singaraja, Buleleng Regency, Indonesia). 5 (31), 241-247.

Liu, C., \& Tsai, W. (2010). The effects of service quality and lifestyle on consumer choice of channel types: The health food industry as an example. African Journal of Business Management, 4 (6), 1023-1039.

Okada, Hitoshi \& Konokwan Atchariyachhanvanich, 2007, How Consumer Lifestyles Affect Purchasing Behavior: Evidence from Internet Shopping In Japan, Journal of Entrepreneurship Research. June 2007, Vol. 2, No. 2, pp. 63-78.

Park, CH, \& Kim, YG (2003). Identifying key factors affecting consumer purchase behavior in an online shopping context. International Journal of Retail \& Distribution Management, $31 \quad 16-29$. https://doi.org/10.1108/09590550310457818

Pattipeilohy, VR, Rofiaty., And MS Idrus. (2013). The Influence of the Availability of Money and Time, Fashion Involvement, Hedonic Consumption Tendency and Positive Emotions Towards Impulse Buying Behavior in Ambon City (Study on 
Purchasing Products Fashion Apparel). International Journal of Business and Behavioral Sciences, Volume 3, Number 8, (36-49).

Rutuja, A., P, GR, S, LS, \& Gadekar, PGB (2020). International Research Journal of Modernization in Engineering Technology and Science ONLINE SHOPPING WITH SENTIMENTAL ANALYSIS FOR FURNITURE SHOP Students, Dept. of Computer Science, Sanjivani College of Engineering, Kopargaon, India. KEYWORDS: Su. 05, 526-530.

Saputra, AM, Lubis, PH, \& Nizam, A. (2020). Factors Impacting Millennial Online Purchase Intention With Web Experience Intensity As Moderation. International Journal of Business Management and Economic Review, 3 (03), 1-16.

Saran, R., S. Roy., And R. Sethuraman. (2016). Personality and Fashion Consumption: A Conceptual Framework In The Indian Context, Journal of Fashion Marketing and Management: An International Journal, Volume 20, Number 2, (157-176).

Scarpi, D. (2006). Fashion stores between fun and usefulness. Journal of Fashion Marketing and Management: An International Journal, 10 (1), 7-24. https://doi.org/10.1108/13612020610651097

Stieler, M., \& Germelmann, CC (2016). Journal of Consumer Marketing. Journal of Consumer Marketing, 33 (6).

Verhagen, T., \& Van Dolen, W. (2011). The influence of online store beliefs on consumer online impulse buying: A model and empirical application. Information and Management, 48 (8), 320-327. https://doi.org/10.1016/j.im.2011.08.001

Verplanken, B., \& Herabadi, A. (2001). Individual differences in impulse buying tendency: Feeling and no thinking. European Journal of Personality, 15 (1 SUPPL.), 71-83. https://doi.org/10.1002/per.423

Zhang, KZK, Xu, H., Zhao, S., \& Yu, Y. (2018). Online reviews and impulse buying behavior: the role of browsing and impulsiveness. In Internet Research (Vol. 28, Issue 3). https://doi.org/10.1108/IntR-12-2016-0377 